(п'ятидесятники, Свідки Сгови, баптисти, адвентисти та ін.). Однак це ніяк не стосується «антикультів» i «контркультів». В СРСР всі значущі питання державно-конфесійних відносин вирішувалися ЦК КПРС, КДБ СРСР і Радою у справах релігій. Таким чином, дії 3 дезорганізації та припинення діяльності «сект» проводилися 3 метою недопущення проникнення агентури потенційного ворога в передвоєнний період і період холодної війни. Подібні дії були частиною державної політики. Вони не можуть бути класифіковані як антисектантський рух.

Чи потрібно боротися 3 сектами та культами? Боротися треба 3 інцидентами порушення чинного законодавства на території тієї чи іншої країни. Злочини коються не тільки всередині НРР, а й усередині традиційних релігій, тим більше, в цивільному секулярному суспільстві. Слід розглядати та розслідувати конкретні інциденти, а не поширювати поодинокі випадки на цілі організації. Дії антисектантів порушують базові права людини, до яких відноситься свобода совісті та віросповідання. Таким чином, антисектантський рух - це деструкція, спрямована не на захист морального та душевного здоров'я суспільства, а на перерозподіл релігійного ринку в інтересах тієї чи іншої пануючої церкви, яка для самолегітимації використовує моральний авторитет в суспільстві та зв'язки з владними структурами.

\title{
1.6 Алекс ОВСIЕНКО. THE POLITICAL DEBATE ON THE WEARING THE FACING VEIL IN GERMANY AND THE BASIC RIGHT OF RELIGIOUS FREEDOM
}

\subsection{Introduction}

The discussions on the ban on burka in Germany started on November the 15 th. 2015 as the party convention of the CSU (a Bavarian part of the ruling CDU) demanded on its party convention to pass the law which would ban the wearing on facial veils in Germany. In the next months the discussion intensified in Germany as more and more politicians got involved in the debate, like the prominent German member of the Free Democratic Party Alexander Graf Lamsdorf or Wolfgang Kubicki, the vice chairman of the FDP which were both in favor of the ban, on the other side there are German politicians like the President of Germany Joachim Gauck or the German minister of justice Heiko Maas who were opposed to ban the wearing of facial veils in Germany.

The German right wing political party the AFD in their basic political program demanded the burkas and other Muslim facial veils to be banned in Germany along with the construction of the minarets, leading to an intensified political discussion on the anti Islamic stance of this party.

These kind of political debate raised concerns whether the ban on the wearing of the facial veil would somehow violate the right of the freedom of religion. The academic service of the German parliament issued an expert opinion in the year 2012 stating that, the ban on wearing of the facial veil would be unconstitional as there are no legal basis which would legally allow banning the wearing on the burka or other Islamic women dress . But the academic service left it open whether the wearing of the facial veil does constitute the breach of the Vermumungsverbot ( Ban on wearing the face covering) A law which proscribes covering the face during demonstration

2-0 Computability between the ban on wearing of the facial veil and the Grundgesetz (Basic Law)

According to the article 4 of the German basic law is the freedom of religion, conscience and the freedom of confessing ones religious or philosophical beliefs are inviolable. The freedom of religion is enhanced by the article 4,2 of the basic law which ensures the right of every person in Germany to practice their religion .

The law of the religious freedom does not only protect the right for every person in Germany to exercise its own religion not only in private but also does it protect the right of every person to express its religious faith in public. By this law not only the f.g the construction of 
churches and other religious buildings is lawfully protected but also the right to wear religious symbols or dress which express ones religious believes .

Whether the wearing of the facial veil is guarded by the article 4 of the German constitution as it cannot be said for sure in every case if every person who wears a facial veil does it as the sign of its religious faith or was this person forced (f.g) by its own family to wear the facial veil. If the latter is the case than the wearing of the facial veil is not protect by the freedom of religion

So in order for the government to justify the banning of a religious actions (like circumcision or wearing of the facial veil) are only than justified if the religious actions if these actions somehow violate some other basic rights It can be argued that the wearing of the facial veil does violate the right of the equality between men and women as many proponents of passing the law to ban facial veils, see it as the symbol for the female oppression. Howe ewer as the academic service of the German parliament states in it s paper on the legality of the ban of the facial veil in Germany, the German government does not have a legal right to interfere into a family affair and to enforce the ban of the facial veil on women who were forced to wear it by their families. As according to the article 16 of the basic law, the family and the marriage is specially protected by the state and only in rare case (f.g if the life of a child is in danger, the state can intervene, as it has to fulfill the obligation to ensure the well being of a child)

Summarized it can be said according to the article 4 of the basic law, the German government does not have the legal right to ban the facial veil as its violate the basic right of the religious freedom and only under special circumstances when other basic rights are infringed by bearing of the facial veil.

\subsection{The debate in the German society on the ban of the facial veil}

The debate on the question whether to pass the law which would ban the wearing of the facial veil focuses mainly on two points. The first point in this debate is the question which has been discussed in Germany since 2010 as the former German president Christian Wullf in his speech at the ceremonial act dedicated to the reunification of Germany stated that Islam together with Christianity and Judaism does belong to Germany. These speech led to a very intensive discussion in this country on the question if the Islamic faith does really belong to Germany.

The opponents of this thesis mainly from the conservative German ruling (CDU -party) although Angela Merkel (in her speech from January the 12 th. 2015) stated that Islam does also belong to Germany, the majority of her party members as well as the Bavarian sister party $\mathrm{CSU}$ and the members of the conservative right wing German political party the AFD claim that the Islam is not a part of German culture as this religion has not had a such great influence on German culture and history like for example the Christianity did. By some opponents is Islam being seen not only as an alien faith but also as a religion which is violates some basic rights which are guaranteed by the German constition (like f.g the equality between men and women) and therefore cannot be considered to be a part of Germany whose identity is build on JudaicChristian values .

Some even (especially the members of the conservative right wing AFD) claim that Islam is not part and has never been the part on Germany as this religion has not made any kind of contribution to German culture, history and society

The supporter of this thesis claim that Islam does belong to Germany as there are over 4 million people of the Islamic faith living in this country for decades, which although this religion has not had such a great impact on German history or culture like f.g the Christianity , the Islam is nevertheless the part of German society .

This discussion on the role on Islam on the German society has also widely influenced the debate on wearing the facing veil. The proponents of the ban see in the facing veil the symbol of a religion (which in their eyes is not only alien to the German society but also dangerous to it. As they make no difference between Islam as a religion and Islamism as a political ideology, claiming that both words have the same meaning . 
For them the facial veil is the man symbol of the radical Islam which for the most people in Germany is associated with terrorism and therefore has to be banned.

The opponents of the ban of the facial veil who are located mostly located on the left of the political spectrum (like members of the Green and Left party) see in this piece of clothing a symbol of the Islamic faith, which has to be protected by the law of religious freedom and the state therefore does not have the right to pass any laws banning the facial veil. The proponents of the ban of the facial veil regard the burka or niqab not as a religious symbol (which has to be protected by the article 4 of the German constitution ) but as a symbol of a dangerous and oppressive faith, which contradicts many basic rights, guaranteed by the Basic Law.

The second point of the discussion is focused on the role of women who wear the facing veil and of the question whether these women do this according to their own will or are their forced to do this by their families for example.

People who are in favor to introduce the ban on the facing veil see this piece of clothing a symbol for the oppression of the women and for the inequality between sexes and demand therefore the burqa or niqab to be banned. By banning of wearing of the facial veil the proponents of the ban want to set a special sign for the liberation of women. Or on the other hand (as there are no independent surveys on the question how high is the percentage of females, wearing the facing veil) both proponents and the opponents cannot say for sure whether the majority of the females who do wear the niqab do this voluntarily or not

Therefore the opponents of the ban, reject the idea to ban the wearing of this Islamic dress as the symbol for " oppression of the women" by saying that are some females who were the niqab by choice and for that reason it is not up to the state to introduce the ban of the facial veil but it s the choice on every women to decide whether to wear the facing veil or not

The proponents of the ban support this idea that some women might wear the niqab voluntarily but at the same time in order to support their idea to ban the facial veil claim that only a tiny majority of females who wear the niqab do this voluntarily while the majority of women in Germany are forced to wear the facing veil and thus in order to protect them it's important to pass the law on which would ban the wearing of the facing veil.

Others opponents of the ban of the facial veil, like the German journalist Christophe Sydow regards the compares the attempts to ban the facial veil with the prohibition for women in some Islamic countries to wear, Western clothes. As he argues in the Spiegel Magazine article that is the liberal and democratic government does not have the legal right to interfere in the daily life of its citizen.

Some opponents of the ban like the German journalist and philosophical writer Christiane Hoffman see in the attempt to ban of the burka as a sign of a culture fight and a method with which the Western world wants to enforce its values on the Islamic world. For her the ban of the facial veil is a symbol for the Western arrogance and of the Western superiority

On the other side there are supporters of the ban of the facial veil (like the German author and journalist Tomas Avenarius) who in his article in the renowned German weekly magazine " Die Zeit argues that the facial veil does clearly violate the basic right of freedom and self determination and for this reason has to be banned. As in his words : " The facial veil is the symbol for fanatism and intolerance .

You can say that the majority of these persons who are in favor of the ban of the facial veil especially use the argument (of the facial veil as a symbol for fanatism and intolerance) to argue for the prohibition of this Islamic piece of cloth. Some politicians from the conservative right wing German party the AFD see in the burka not only as a symbol of fanatism and intolerance but as something which is totally alien to German and European culture.

So in order to summarize this essay you can state as I have already mentioned above the ban of the facial veil would be a violation of the basic principle of the right of the religious freedom and thus would be a breach of the article 4 of the German constition. And therefore the 
state cannot ban the burka or any other Islamic dress for religious reasons or as the AFD party claims ( that the facial veil is not a part of the Western culture) It can of course be argued if by introducing the ban on the facial veil, the state would be acting in the interest of the females who have been forced to wear, but what about the women who wear this piece of cloth as the sign of their religious affiliation because in that case the government would act against the principle of the religious freedom.

So it is a very tricky question and therefore the ban of the bukas as the whole in my opinion would not help the females who have been forced to wear it by their families for example as their would now be probably not allowed to leave the house furthermore the ban would not solve the problem of female discrimination in some parts of Muslim society as this problem is more deep rooted andcomplex and therefore cannot be solved byputting only the ban on wearing facial veil.

In my opinion it's not up to the state to intervene into the private life of its citizen and introduce the ban on the piece of cloth only because it does not represent the Western values. Since in this case (if the wearing of the facial veil will only be prohibited for religious reason) it would represent a clear violation of the basic right of the religious freedom.

And if this is the case, than Germany or any other Western country would act as undemocratic country like Iran or Saudi Arabia where females are banned from wearing certain clothes which are considered to violate against the modesty in Islam. 